\title{
Organochlorine Pesticides in Selected Sewage Sludge in South Africa : Assessment and Method Validation
}

\author{
Olufemi T. Ademoyegun ${ }^{1 *}$, Omobola O. Okoh², Anthony I. Okoh ${ }^{3}$ \\ ${ }^{1}$ Department of Pure and Applied Chemistry, University of Fort Hare, Alice, South Africa, SAMRC, \\ Microbial Water Quality Monitoring Centre, University of Fort Hare, National Horticultural Research Institute, \\ Ibadan, Oyo State, Nigeria \\ ${ }^{2}$ Department of Pure and Applied Chemistry, University of Fort Hare, Alice, South, SAMRC, \\ Microbial Water Quality Monitoring Centre, University of Fort Hare \\ ${ }^{3}$ SAMRC, Microbial Water Quality Monitoring Centre, University of Fort Hare, Applied and Environmental \\ Microbiology Research Group, Department of Biochemistry and Microbiology, \\ University of Fort Hare, Alice, South Africa
}

Received: 15 August 2018

Accepted: 8 October 2018

\begin{abstract}
The purpose of this study was to determine the concentrations of organochlorine pesticides (OCPs) in sewage sludge from three wastewater treatment plants (WWTPs), with a view to study their contribution to the environmental pollution of the Amathole District in Eastern Cape, South Africa. Analyses were performed by gas chromatography joined with micro electron capture detector $(\mu \mathrm{ECD})$. The limits of detection (LODs) of the tested congeners varied from $0.04 \mathrm{ng} / \mathrm{g} \alpha$-Lindane ( $\alpha$-BHC) to $0.49 \mathrm{ng} / \mathrm{g}$ (endosulfan sulfate), and the limits of quantification ranged from $0.22 \mathrm{ng} / \mathrm{g}$ (aldrin) to $2.17 \mathrm{ng} / \mathrm{g} \delta$-lindane $(\delta$-BHC). Total concentrations of the 17 congeners for different seasons in the sludge ranged from 191 to $947 \mathrm{ng} / \mathrm{g} \mathrm{dw}$. For the six predominant congeners, the total highest concentration levels were found in this order dichlorodiphenyl trichloroethane (DDT), dichlorodiphenyl dichloroethane (DDD), $\alpha$-BHC, $\gamma$-BHC, aldrin and endosulphate 1, and with values of 1512, 1330, 1095, 998, 994 and $547 \mathrm{ng} / \mathrm{g}$ respectively. For this result the contamination levels of some congeners for South African sludge can be categorized as high compared with European countries, but moderate to lower compared to other countries worldwide. Some congener $(\alpha-B H C, \gamma$-BHC, aldrin, endosulphate 1 , DDD and DDT) contents in the samples exceeded limits set by the European Commission for $1000 \mathrm{ng} / \mathrm{g}$ set for $\Sigma$ DDT and $500 \mathrm{ng} / \mathrm{g}$ for other pesticide use of sludge in agriculture.
\end{abstract}

Keywords: sewage sludge, wastewater treatment plants, gas chromatography $/ \mu \mathrm{ECD}$, organochloride pesticides, South Africa

*e-mail: femtopyankee@gmail.com 


\section{Introduction}

Organochlorine pesticides (OCPs) are harmful chemicals used to destroy or control pesticides that are destroying food or crop production. The widespread use of pesticides to increase agricultural productivity has played a major role in recent decades. The chemicals have been applied for many years to avert, repel or mitigate the effects of pests [1-3]. One common nature of OCPs are their persistence in the environment, and many countries have banned their use because of their genotoxic and carcinogenic effects. Their metabolites are still present in the environs owing to their persistence, and are more harmful than their parent compounds. The toxicity, bioaccumulation and longer half-lives of the compounds present a high level of risk to the environment [4-5]. Organochlorine pesticides (OCPs) move in the environment through non-point sources such as agricultural runoff and vapourization following their field application. OCPs are highly lipophilic and tend to adsorb solid particles of sewage in wastewater treatment plants (WWTPs). Therefore, sewage sludge can be one of the major sources of these ecological pollutants when they are applied as landfill or agricultural manure. In addition, their concentration in sewage sludge can be indicative of the environmental release of the compounds [6-7].

The majority of organochlorides that are banned in South Africa are still in use, causing various hazard effects to ecosystems. A study from the Jukskei River catchment area in Gauteng, South Africa showed a significant high level concentration of OCPs in all the sampling points [8-9]. There were also some studies monitoring OCPs in sewage sludge in Europe [4, 10]. The European Union has developed the draft of a "working document on sludge" to promote the use of sewage sludge in agriculture with limit values set for several heavy metals and some organic compounds, including seven PCB congeners (maximum limit of $800 \mathrm{ng} / \mathrm{g}$ ). For OCPs a value of $1,000 \mathrm{ng} / \mathrm{g}$ was established as the highest contaminant limit of $\Sigma$ DDTs, and $500 \mathrm{ng} / \mathrm{g}$ for other pesticides [11-13]. Due to the ecological risk of the aforementioned compounds to both human and aquatic organisms, it is therefore very important to constantly examine the pesticide residues in the environments [14-15]. There is also a need for development and validation of methods with higher sensitivity, reliability, and accuracy. Most common methods for the identification and quantification of pesticide residues were based on using gas chromatography with electron capture detector (ECD), mass spectrometer (MS) and Flame ionization detector (FID) $[7,10] . \mu$-ECD is very sensitive for the analysis of halogenated compounds [16-18].

The aim of this work was to develop and validate methods using GC- $\mu \mathrm{ECD}$ detectors for determining pesticide residues in the environment. These methods were applied to determine the concentration of OCP residues in the sludge collected from three WWTPs in Eastern Cape, South Africa. To the best of our knowledge, there is no data on the concentration levels of OCPs in the sewage sludge in this area. The objectives of this study were to investigate the levels and compositions of organochlorine pesticides in the sludge of three WWTPs around Amathole municipality in Eastern Cape, South Africa. Screen sewage sludge samples to determine the existence of the most persistent organic pollutants, test the extraction method for efficiency and reproducibility, quantify the selected organic contaminants and compare the values obtained in this work to the current European commission Sludge Guidelines and make recommendations [19]. Due to a lot of farming activities, the area around this site was suspected to be contaminated by pesticide residues as a result of leakage and improper disposal of pesticides and containers. No study had been conducted to investigate the contamination status at this site.

\section{Material and Method}

A mixed standard of the organochlorine $(\alpha, \beta, \gamma$, and $\delta$ - hexachlorocyclohexane $(\mathrm{HCH})$, heptachlor, heptachlor epoxide, dieldrin, aldrin, endrin, endrin aldehyde, endosulfan I, endosulfan II, endosulfan sulfate, p,p'-DDE, p,p'-DDD, p,p'-DDT, and methoxychlor) was purchased from Sigma-Aldrich in a solvent mixture, with each of concentration $2000 \mu \mathrm{g} / \mathrm{ml}$ in (acetone:toluene). The internal standard used was pentachloronitrobenzene (99\%) from Aldrich (Germany). Other solvents of residue-free purity (99.1\%) purchased from Merck Co. (Germany) and used for this study were acetone, methanol, ethyl acetate, hexane, dichloromethane, sodium chloride and sodium sulfate. Milli-Q water purification system from Millipore (Bedford, MA, USA) was used to prepare all aqueous solutions. A stock solution containing the mixed analytes $(20 \mathrm{mg} / \mathrm{mL})$ was prepared by dissolving $0.5 \mathrm{~mL}$ of standard solution in a $50 \mathrm{~mL}$ volumetric flask with acetone:toluene $(1: 1) \mathrm{vol} / \mathrm{vol}$ and stored at $-4^{\circ} \mathrm{C}$.

\section{Sampling}

Wastewater sludge samples were collected from three wastewater treatment plants (WWTPs) operating with a conventional activated sludge process - all located in the Amathole District municipality in Eastern Cape, South Africa. The sampling map and locations of the three plants are shown in Fig. 1. The samples analyzed were of urban and agricultural origins with animal rearing, citrus orchard and other crop-farming activities and animal-rearing origin. Sampling was carried out in spring 2015 (October and November), summer 2016 (January and February), autumn 2016 (April and May) and winter 2016 (July and August) in order to reflect the seasonal variability in sludge contaminant concentrations as much as possible. In each 


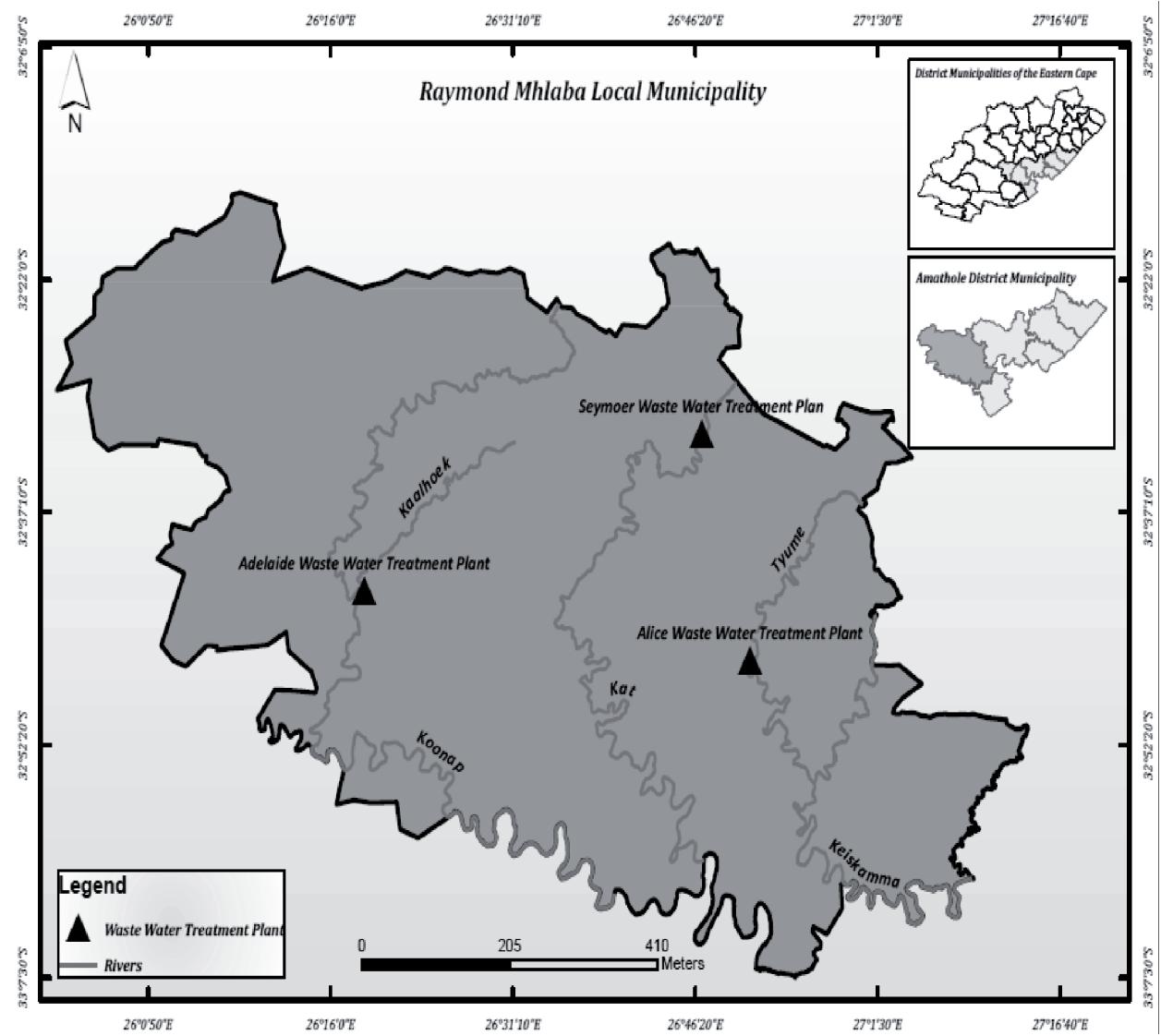

Fig. 1. Map of the sampling sites with the representation of the sampling points of the WWTPs and surrounding rivers in Eastern Cape, South Africa.

season, grab samples of sludge $(n=3)$ were collected from the WWTPs twice monthly over a period of two months into $2 \mathrm{~L}$ wide-mouth bottles from the dewatered activated sludge cake, which is the final residue of wastewater treatment processes. The sludge samples were composited in a stainless steel bucket, transported in a cooler box with ice to the laboratory and stored in a refrigerator at $4^{\circ} \mathrm{C}$ until they were analysed. The collected sludge samples were dried at room temperature, ground to homogenize and maintained at $-4^{\circ} \mathrm{C}$ prior to extraction.

\section{Extraction Procedure}

The extraction of OCPs in the sewage sludge was carried out as follows. Weight $2 \mathrm{~g}$ of the dried sludge was extracted with $20 \mathrm{~mL}$ dichloromethane-acetone (1:1 $\mathrm{v} / \mathrm{v}$ ) for $30 \mathrm{~min}$ using ultrasonication and performed twice. The solvent extracts were pooled together and the activated $\mathrm{Cu}$ was added to remove element sulfate, then follow by dehydrated with anhydrous sodium sulfate. A rotary evaporator was further used to concentrated the extracts to about $1-2 \mathrm{~mL}$, and later placed in a glass column (12 mm i.d.) loaded with $10 \mathrm{~g}$ activated Florisil (60-100 mesh) for purification, and subsequently eluated with $10 \mathrm{~mL}$ hexane containing $10 \%$ acetone $(\mathrm{v} / \mathrm{v})$. The eluate was further concentrated to $0.1 \mathrm{~mL}$ under a gentle stream of pure nitrogen and injected into GC analysis.

\section{$\mathrm{GC} / \mu \mathrm{ECD}$ Analysis}

The OCP was determined using GC/ $\mu$-ECD (Agilent Technologies, CA, USA) equipped with a doubledetector FID and GC/ $\mu$-ECD. $1 \mu \mathrm{L}$ of the purified sample extracts were injected into a fused-silica capillary column (30 m $\times 0.32 \mathrm{~mm}$ id) coated with $0.25 \mu \mathrm{m}$ chemically bonded HP-5 phase. $99.9 \%$ purity of helium gas was used as the carrier gas at a linear velocity of $2.4 \mathrm{~mL} / \mathrm{min}$ and auxiliary gas $\left(\mathrm{N}_{2}\right)$ at a linear velocity of $40 \mathrm{~mL} \mathrm{~min}{ }^{-1}$. The oven was held at $100^{\circ} \mathrm{C}$ for $1 \mathrm{~min}$, and ramped up at $20^{\circ} \mathrm{C}$ per min to $180^{\circ} \mathrm{C}$, at $5^{\circ} \mathrm{C} / \mathrm{min}$ to $270^{\circ} \mathrm{C}$, and at $20^{\circ} \mathrm{C} / \mathrm{min}$ to $320^{\circ} \mathrm{C}$. The detector was operated at $320^{\circ} \mathrm{C}$ and injector temperature at $250^{\circ} \mathrm{C}$.

\section{Results and Discussion}

\section{Method Validation}

To perform the quality assurance step a recovery study of the analytes was carry out under the same conditions as those expressed for the samples. The sludge samples were spiked and the recovery 
Table 1. Mean recoveries $(\%)$ and standard deviation $(n=3)$ and repeatability of the target compounds in spiked water and sludge samples.

\begin{tabular}{|c|c|c|c|c|}
\hline \multirow{2}{*}{ Congeners } & \multicolumn{3}{|c|}{ Recoveries of the studied OCPs in sewage sludge } & \multirow{2}{*}{$\begin{array}{c}\text { Repeatability } \\
\operatorname{RSD}(\%) n=6\end{array}$} \\
\hline & $50 \mathrm{ng} / \mathrm{g}$ & $100 \mathrm{ng} / \mathrm{g}$ & $200 \mathrm{ng} / \mathrm{g}$ & \\
\hline$\alpha-\mathrm{BHC}$ & $102 \pm 3.4$ & $105.1 \pm 3.9$ & $99.6 \pm 4.1$ & 5.7 \\
\hline$\beta-\mathrm{BHC}$ & $99.5 \pm 5.4$ & $90.2 \pm 2.8$ & $88.4 \pm 3.1$ & 8.9 \\
\hline$\gamma$-BHC & $93.2 \pm 4.8$ & $97.6 \pm 2.9$ & $87.6 \pm 4.1$ & 5.2 \\
\hline$\delta$-BHC & $88.5 \pm 3.1$ & $93.5 \pm 3.5$ & $96.8 \pm 5.1$ & 3.5 \\
\hline HEPTACHLOR & $104.5 \pm 2.9$ & $101.2 \pm 2.8$ & $93.6 \pm 3.8$ & 7.8 \\
\hline ALDRIN & $98.5 \pm 3.9$ & $88.9 \pm 3.1$ & $93.5 \pm 3.9$ & 9.6 \\
\hline HEPTACHLOR EPOXIDE & $88.5 \pm 1.9$ & $81.6 \pm 4.2$ & $85.2 \pm 4.1$ & 5.2 \\
\hline ENDOSULFAN 1 & $91.5 \pm 3.8$ & $95.8 \pm 5.3$ & $99.1 \pm 4.9$ & 4.9 \\
\hline 4,4-DDE & $107.4 \pm 3.7$ & $103 \pm 4.4$ & $98.5 \pm 2.8$ & 7.8 \\
\hline DIELDRIN & $83.6 \pm 4.1$ & $86.5 \pm 3.5$ & $93.6 \pm 4.4$ & 6.5 \\
\hline ENDRIN & $88.2 \pm 2.5$ & $84.6 \pm 3.3$ & $91.2 \pm 3.1$ & 6.1 \\
\hline 4, 4, DDD & $102.4 \pm 4.2$ & $105 \pm 5.1$ & $95.6 \pm 4.7$ & 5.9 \\
\hline ENDOSULFAN 11 & $82.5 \pm 3.1$ & $86.5 \pm 3.2$ & $89.9 \pm 2.6$ & 5.2 \\
\hline $4,4, \mathrm{DDT}$ & $80.1 \pm 3.9$ & $85.4 \pm 2.1$ & $88.5 \pm 2.2$ & 4.1 \\
\hline ENRIN AIDEHYDE & $95.7 \pm 1.8$ & $91.7 \pm 2.8$ & $86.8 \pm 2.1$ & 3.9 \\
\hline ENDOSULFAN SULFATE & $92.6 \pm 1.7$ & $97.5 \pm 3.2$ & $94.3 \pm 2.6$ & 6.7 \\
\hline METHOXYCHLOR & $97.5 \pm 2.3$ & $88.5 \pm 3.6$ & $90.5 \pm 3.8$ & 8.5 \\
\hline
\end{tabular}

determined from the concentration differences between the spiked samples and the unspiked samples with 3 replicate analyses. Extractions were carried out at three fortification levels: 50, 100 and $200 \mathrm{ng} / \mathrm{g}$. The spiked sludge was allowed to be kept for $14 \mathrm{~h}$ to enable the spiked compounds to assimilate with the sample matrix. To limit the effects of enzymatic activities and microbial biotransformation it was kept in a refrigerator during this period. To measure the reproducibility/ precision of the method, sample analyses and recovery study were carried out in triplicate. Table 1 shows the mean recovery values with the relative standard deviations. For every batch of sample analysis, blank analyses were also carried out along with measuring the likely influences from external sources during analysis. The method linearity was studied in the range 5-320 $\mu \mathrm{g} / \mathrm{L}$. Calibration curves showed satisfactory correlation coefficients (greater than 0.99). To determine the repeatability of the chromatograph, this was performed by injecting 7 times a standard solution of $0.4 \mu \mathrm{g} / \mathrm{mL}$ with an automatic injector (Fig. 2). The peak areas obtained values ranging from 0.40 to $4.04 \%$, whereas the relative standard deviations (RSD) generated for the retention times ranged from 0.01 to $0.03 \%$ (Table 2). For determining the chromatographic within-laboratory reproducibility, this was estimated during different days during two repeated weeks and was found to be lower than $10 \%$, expressed as RSD, for all OCPs. Results are shown in Table 1. In all the fortification levels, recoveries were in the range of $80.1-107.4 \%$, whereas RSD values ranged from 1.7 to $5.4 \%$, thus satisfying the requirements of the European Union Guideline [20]. The values obtained are comparable to the recoveries reported by other authors using supercritical fluid extraction [21], pressurized liquid extraction [22] or Soxhlet extraction [23-26] for the analysis of OCPs in environmental samples.

\section{Limits of Detection (LOD) and Quantification (LOQ)}

Limits of detection (LODs) and quantification (LOQs) measured as the least amount of target analyte that yields a chromatogram peak with a signal-to-noise ratio of three and ten times the background chromatographic noise, respectively, were determined using extracts from blank samples. Low limits were obtained due to the selectivity of the analytical procedure and the high sensitivity of $\mathrm{GC}-\mu \mathrm{ECD}$, permitting the determination of OCPs at the levels found in sludge samples. The LODs and LOQs corresponding to the different OCPs are shown in Table 2. These values range from 0.04 to $0.49 \mathrm{ng} / \mathrm{g}$ for LODs and from 0.22 to $2.17 \mathrm{ng} / \mathrm{g}$ for LOQs and are in the lower end of those reported by other authors [24, 27-30]. 


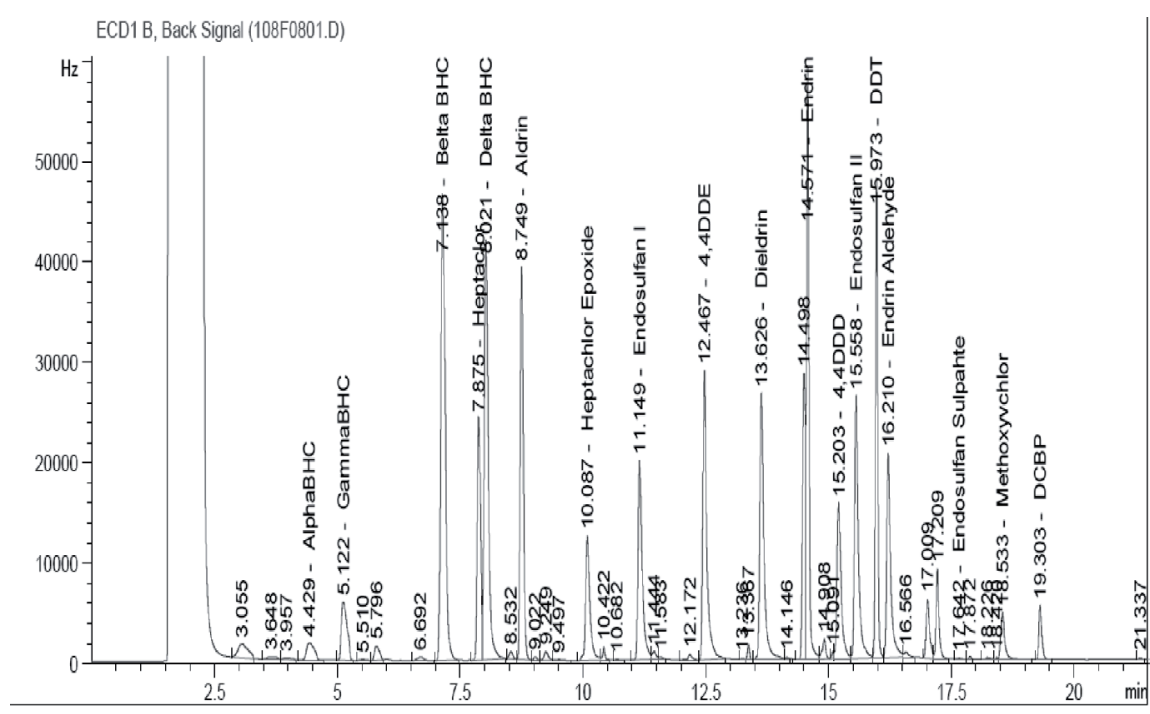

Fig. 2. Chromatogram of $0.4 \mu \mathrm{g} / \mathrm{mL}$ injected seven times for repeatability.

\section{Concentration of OCPs in Sewage Sludge Samples}

Sludge samples collected from three municipal wastewater treatment plants (MWWTPs) in the Eastern Cape Province located in urban and rural sites, were analyzed with a validated method. The concentrations of OCPs found in sewage sludge are expressed as $\mathrm{ng} / \mathrm{g}$ dry weight. Table 3 shows the highest concentration of OCPs expressed as the summation of the 17 compounds found in WWTP1 $(947 \mathrm{ng} / \mathrm{g})$ and the lowest concentration in WWTP3 (191 ng/g). WWTP1 is a rural area where a lot of farming activities are carried out, especially citrus orchards, therefore the agricultural activities may be the reason for the high concentration in this site. The lowest concentration was found in an urban area with fewer farming activities around the treatment plant. Total OCP concentrations are higher than the values reported by other researchers [18, 31], although a similar range of values was found in an

Table 2. Calibration data and repeatability of the studied OCPs.

\begin{tabular}{|c|c|c|c|c|c|c|}
\hline Congeners & Calibration data equation & $\mathrm{R}^{2}$ & $\mathrm{RSD}\left(\mathrm{t}_{\mathrm{r}}\right)$ & LOD ng $\mathrm{g}$ & LOQ ng/g & Area RSD $\%$ \\
\hline$\alpha$-BHC & $\mathrm{y}=13833 \mathrm{x}-4389$ & 0.9951 & 0.01 & 0.04 & 0.28 & 2.45 \\
\hline$\beta$-BHC & $\mathrm{y}=99379 \mathrm{x}-15367$ & 0.9928 & 0.01 & 0.28 & 0.31 & 1.56 \\
\hline$\gamma$-BHC & $\mathrm{y}=64859 \mathrm{x}-46461$ & 0.9956 & 0.02 & 0.08 & 1.19 & 1.36 \\
\hline$\delta$-BHC & $\mathrm{y}=325750 \mathrm{x}-194418$ & 0.9948 & 0.02 & 0.05 & 2.17 & 1.87 \\
\hline HEPTACHLOR & $\mathrm{y}=303236 \mathrm{x}-29840$ & 0.9949 & 0.01 & 0.31 & 0.32 & 0.89 \\
\hline HEP EPOXIDE & $\mathrm{y}=40636 \mathrm{x}-4826$ & 0.9944 & 0.03 & 0.15 & 2.11 & 4.04 \\
\hline ALDRIN & $\mathrm{y}=107562 \mathrm{x}-13109$ & 0.9938 & 0.01 & 0.21 & 0.22 & 1.42 \\
\hline ENDOSULFAN & $\mathrm{y}=192696 \mathrm{x}-91905$ & 0.9962 & 0.02 & 0.33 & 1.31 & 0.40 \\
\hline $4,4-$ DDE & $\mathrm{y}=334989 \mathrm{x}-254724$ & 0.9958 & 0.02 & 0.48 & 0.38 & 0.55 \\
\hline DIELDRIN & $\mathrm{y}=155561 \mathrm{x}-1507$ & 0.9937 & 0.01 & 0.43 & 0.54 & 1.79 \\
\hline ENDRIN & $\mathrm{y}=326806 \mathrm{x}-235886$ & 0.9969 & 0.03 & 0.09 & 1.53 & 1.11 \\
\hline 4,4, DDD & $\mathrm{y}=119133 \mathrm{x}-126127$ & 0.9969 & 0.02 & 0.21 & 0.28 & 1.50 \\
\hline ENDOSULFAN 11 & $\mathrm{y}=351175 \mathrm{x}-348939$ & 0.9945 & 0.03 & 0.45 & 1.21 & 3.12 \\
\hline 4,4, DDT & $\mathrm{y}=32161 \mathrm{x}-2506$ & 0.9978 & 0.03 & 0.31 & 0.33 & 3.08 \\
\hline ENRIN AIDEHYDE & $\mathrm{y}=58541 \mathrm{x}-65935$ & 0.9991 & 0.02 & 0.35 & 0.27 & 1.55 \\
\hline ENDOSULFAN SULFATE & $\mathrm{y}=14084 \mathrm{x}-9954$ & 0.9994 & 0.02 & 0.49 & 1.31 & 1.83 \\
\hline METHOXYCHLOR & $\mathrm{y}=8430 \mathrm{x}-9942$ & 0.9924 & 0.01 & 0.38 & 1.38 & 3.41 \\
\hline
\end{tabular}


Table 3. Concentrations of OCPs (ng/g) in sewage sludge collected in three activated sludge WWTPs for a whole year.

\begin{tabular}{|c|c|c|c|c|c|c|c|c|c|c|c|c|c|}
\hline \multirow{2}{*}{ Congeners } & \multicolumn{4}{|c|}{ WWTP1 } & \multicolumn{4}{|c|}{ WWTP2 } & \multicolumn{4}{|c|}{ WWTP3 } & \multirow{2}{*}{$\sum_{\text {congeners }}^{\sum}$} \\
\hline & $\begin{array}{l}\text { OCT- } \\
\text { NOV }\end{array}$ & $\begin{array}{l}\text { JAN- } \\
\text { FEB }\end{array}$ & $\begin{array}{l}\text { APR- } \\
\text { MAY }\end{array}$ & $\begin{array}{c}\text { JY- } \\
\text { AUG }\end{array}$ & $\begin{array}{l}\text { OCT- } \\
\text { NOV }\end{array}$ & $\begin{array}{l}\text { JAN- } \\
\text { FEB }\end{array}$ & $\begin{array}{l}\text { APR- } \\
\text { MAY }\end{array}$ & $\begin{array}{c}\text { JY- } \\
\text { AUG }\end{array}$ & $\begin{array}{l}\text { OCT- } \\
\text { NOV }\end{array}$ & $\begin{array}{l}\text { JAN- } \\
\text { FEB }\end{array}$ & $\begin{array}{l}\text { APR- } \\
\text { MAY }\end{array}$ & $\begin{array}{c}\text { JY- } \\
\text { AUG }\end{array}$ & \\
\hline$\alpha-\mathrm{BHC}$ & 160 & 98 & 158 & 131 & 115 & 32 & 68 & 78 & 98 & 43 & 48 & 66 & 1095 \\
\hline$\beta-\mathrm{BHC}$ & 12 & n.d. & n.d. & 8 & 34 & 12 & 15 & 41 & n.d. & n.d. & n.d. & n.d. & 122 \\
\hline$\gamma$-BHC & 270 & 23 & 150 & 76 & 105 & 66 & 87 & 77 & 77 & n.d. & 42 & 21 & 994 \\
\hline$\delta$-BHC & 15 & 9 & 12 & 11 & 9 & 11 & 13 & 17 & n.d. & n.d. & n.d. & n.d. & 97 \\
\hline НЕРТА & n.d. & n.d. & n.d. & n.d. & n.d. & n.d. & n.d. & n.d. & n.d. & n.d. & n.d. & n.d. & \\
\hline ALDRIN & 121 & 67 & 88 & 107 & 141 & 120 & 105 & 110 & 58 & 23 & 25 & 33 & 998 \\
\hline HEP ЕРО & n.d. & n.d. & n.d. & n.d. & n.d. & n.d. & n.d. & n.d. & n.d. & n.d. & n.d. & n.d. & \\
\hline END 1 & 99 & 51 & 88 & 66 & 40 & 49 & 62 & 72 & 12 & n.d. & n.d. & 8 & 547 \\
\hline $4,4-\mathrm{DDE}$ & 34 & 45 & 32 & 41 & 33 & 23 & 43 & 21 & 32 & 12 & 23 & 29 & 368 \\
\hline DIELDRIN & n.d. & n.d. & n.d. & n.d. & n.d. & n.d. & n.d. & n.d. & n.d. & n.d. & n.d. & n.d. & \\
\hline ENDRIN & n.d. & n.d. & n.d. & n.d. & n.d. & n.d. & n.d. & n.d. & n.d. & n.d. & n.d. & n.d. & \\
\hline $4,4, \mathrm{DDD}$ & 108 & 77 & 108 & 132 & 145 & 133 & 139 & 169 & 99 & 56 & 89 & 75 & 1330 \\
\hline END 11 & n.d. & n.d. & n.d. & n.d. & n.d. & n.d. & n.d. & n.d. & n.d. & n.d. & n.d. & n.d. & \\
\hline $4,4, \mathrm{DDT}$ & 128 & 220 & 165 & 131 & 150 & 101 & 144 & 120 & 108 & 57 & 89 & 99 & 1512 \\
\hline ENRIN AIDE & n.d. & n.d. & n.d. & n.d. & n.d. & n.d. & n.d. & n.d. & n.d. & n.d. & n.d. & n.d. & \\
\hline END SUL & n.d. & n.d. & n.d. & n.d. & n.d. & n.d. & n.d. & n.d. & n.d. & n.d. & n.d. & n.d. & \\
\hline METHO & n.d. & n.d. & n.d. & n.d. & n.d. & n.d. & n.d. & n.d. & n.d. & n.d. & n.d. & n.d. & \\
\hline$\Sigma 17$ OCPs & 947 & 590 & 801 & 703 & 772 & 547 & 676 & 705 & 484 & 191 & 316 & 331 & \\
\hline
\end{tabular}

Results are the mean of four samplings, n.d.: $<$ method detection limit.

urban sludge as published by [7, 32-35]. In our study, $\alpha$-BHC, Aldrin, DDE, DDT and DDD are the five most ubiquitous compounds with frequency of detection of $100 \%$. Other compounds that were detected with their percentage frequency are $\beta$-BHC (50\%), $\gamma$-BHC (92\%), $\delta$-BHC $(67 \%)$, and endosulphate I (84\%). Conversely, other organochlorine pesticides (including heptachlor, heptachlor epoxide, dieldrin, endrin, endosulphate- II, endrin aldehyde, endosulfan sulphate, and methoxychor) were not detectable. These results are consistent with those of related studies on sewage sludge [32-35]. The highest concentrations of DDT, DDD and DDE detected ranged from 12 to $220 \mathrm{ng} / \mathrm{g}$. For both the $\alpha-\mathrm{BHC}$ and the aldrin concentrations in the sewage sludge, the levels varied from 32-160 ng/g and 23-121 ng/g respectively. For $\beta, \gamma$, and $\delta$-BHC, concentrations were in the range of 9-270 $\mathrm{ng} / \mathrm{g}$ and endosulphate I was detected in concentrations ranging from 8 to $99 \mathrm{ng} / \mathrm{g}$ (Table 3). The use of OCPs has been banned in many countries, including South Africa, where DDT is still used by government official for malaria vector control in some parts of the country, and DDT sticks strongly to sludge particles and does not move quickly to wastewater [8-9]. These groups of OCPs may still be used secretly under an unknown trade name in crop farming due to their low cost and effectiveness for pest control [36-39]. Among the six predominant congeners, the total highest concentration levels were found in the order: $\Sigma D D T, \Sigma D D D$, $\Sigma \alpha$-BHC, $\Sigma \gamma$-BHC, $\Sigma$ aldrin and $\Sigma$ endosulfate 1 with values 1512, 1330, 1095, 998, 994 and $547 \mathrm{ng} / \mathrm{g}$ respectively (Table 3). The European commission sludge guideline to promote the use of sewage sludge in agriculture with limit values set for OCPs with a value of 1,000 ng/g was established as the highest contaminant limit of $\mathrm{DDDTs}$, and $500 \mathrm{ng} / \mathrm{g}$ for other pesticides. The results showed that the six predominant congeners exceed the set limit. Other authors reported similar values and higher values of total congeners in other countries of the world $[11,31]$.

\section{Conclusions}

This work presents a validated, simple and rapid method for simultaneous quantification of 17 compounds of organochlorine pesticides in sludge samples. A good validation of method with good recovery of the congeners in the sludge matrixes was obtained. The present study 
assessed the concentrations and distribution levels of OCPs in sewage sludge samples from three WWTPs in the Amathole District, Eastern Cape, South Africa, and added to the scarce knowledge of their environmental distribution in sludge from South Africa. Due to a variety of potential inputs from several sources, OCP contaminants were ubiquitously distributed in the sludge samples investigated. Total OCP (17 compounds) concentrations ranged from 191 to $947 \mathrm{ng} / \mathrm{g}$, which were higher than the proposed EU limit. In relation to similar studies on sewage sludge worldwide, contamination levels of OCPs were at comparable levels with those reported for other WWTPs. DDT is the congener with highest concentration throughout the year. Hence, the OCP concentrations in sludge in South Africa were generally higher than for some EU countries, which are believed to be linked to the protracted use of DDTs in South Africa. It is concluded that WWTPs remain potential sources of toxic contaminants to the local environment. Therefore, stringent control measures should be considered for protecting or restoring sewage sludge quality. As the current study is not representative of sewage sludge production in South Africa, there is a need to implement research and monitoring program priorities for OCPs and other emerging pollutants in sewage sludge.

\section{Acknowledgements}

We are grateful to the South Africa Medical Research Council (grant No. MRC-RFA-GSAD-02-2014-UFH) and Govan Mbeki Research and Development Centre, University of Fort Hare for financial support.

\section{Conflict of Interest}

The authors wish to declare that there is no conflict of interest regarding the publication of this manuscript.

\section{References}

1. AKHTAR M., MAHBOOB S., SULTANA S., SULTANA T., ALGHANIM K.A., AHMED Z. Assessment of pesticide residues in flesh of Catla catla from Ravi River, Pakistan. Sci World J 2014, 2014.

2. WEI J.-C., HU J., CAO J.-L., WAN J.-B., HE C.-W., HU Y.J., HU H., LI P. Sensitive Detection of Organophosphorus Pesticides in Medicinal Plants Using Ultrasound-Assisted Dispersive Liquid-Liquid Microextraction Combined with Sweeping Micellar Electrokinetic Chromatography. J Agric Food Chem. 64, 932, 2016.

3. CCANCCAPA A., MASIÁ A., NAVARRO-ORTEGA A., PICÓ Y., BARCELÓ D. Pesticides in the Ebro River basin: Occurrence and risk assessment. Environ Pollut. 211, 414, 2016.

4. OZCAN S., TOR A., AYDIN M.E. Analytical Methods for Viable and Rapid Determination of Organochlorine
Pesticides in Water and Soil Samples. Pesticide. 59, 2009.

5. ZHAO L., DONG Y.H., WANG H. Residues of organochlorine pesticides and polycyclic aromatic hydrocarbons in farm-raised livestock feeds and manures in Jiangsu, China. Sci Total Environ. 450 (451), 348, 2013.

6. BARAKAT A.O., KHAIRY M., AUKAILY I. Persistent organochlorine pesticide and $\mathrm{PCB}$ residues in surface sediments of Lake Qarun, a protected area of Egypt. Chemosphere. 90 (9), 2467, 2013.

7. BARAKAT A.O., KHAIRY M.A., MAHMOUD M.R. Organochlorine pesticides and polychlorinated biphenyls in sewage sludge from Egypt. J Environ Sci Health A Tox Hazard Subst Environ Eng. 0, 1, 2017.

8. SIBALI L.L., OKWONKWO J.O., MCCRINDLE R.I. Determination of selected organochlorine pesticide (OCP) compounds from the Jukskei River catchment area in Gauteng, South Africa. Water SA. 34, 611, 2008.

9. OKONKWO J.O., SIBALI L.L., McCRINDLE R., SENWO Z.N. An improved method to quantify dichlorodiphenyltrichloroethane (DDT) in surface water using activated carbon. Environ. Chem Lett 5 (3), 121, 2007.

10. MATISOVÁ E., HROUZKOVÁ S. Analysis of endocrine disrupting pesticides by capillary GC with mass spectrometric detection. 9, 2012.

11. CLARKE B.O., PORTER N.A., MARRIOTT P.J., BLACKBEARD J.R. Investigating the levels and trends of organochlorine pesticides and polychlorinated biphenyl in sewage sludge. Environ. Int. 36 (4), 323, 2010.

12. PAL A., GIN A.Y-C., REINHARD M. Impacts of emerging organic contaminants on freshwater resources: Review of recent occurrences, sources, fate and effects. Science of the Total Environment 408, 6062, 2010.

13. LAWS B.V., DICKENSON E.R.V., JOHNSON T.A., SNYDER S.A., DREWES J.E. Attenuation of contaminants of emerging concern during surface-spreading aquifer recharge. Science of the Total Environment 409, 1087, 2011.

14. TOLOSA I., MESA-ALBERNAS M., ALONSOHERNANDEZ C.M. Organochlorine contamination PCBs, DDTs, HCB, HCHs in sediments from Cienfuegos bay, Cuba. Mar. Pollut. Bull. 60 (9), 1619, 2010

15. TANG, H.P. Recent development in analysis of persistent organic pollutants under the Stockholm Convention. Tr. Anal. Chem. 45, 48, 2013

16. EL-SHAHAWI M.S., HAMZA A., BASHAMMAKH A.S., AL-SAGGAF W.T. An overview on the accumulation, distribution, transformations, toxicity and analytical methods for the monitoring of persistent organic pollutants. Talanta. 80 (5), 1587, 2010.

17. WILSON J., BERNTSEN H.F., ZIMMER K.E., FRIZZELL C., VERHAEGEN S., ROPSTAD E., CONNOLLY L. Effects of defined mixtures of persistent organic pollutants (POPs) on multiple cellular responses in the human hepatocarcinoma cell line, HepG2, using high content analysis screening. Toxicol. Appl. Pharm. 294, 21, 2016.

18. RIVERA-UTRILLA J., SÁNCHEZ-POLO M., FERROGARCÍA MÁ., PRADOS-JOYA G., OCAMPO-PÉREZ R. Pharmaceuticals as emerging contaminants and their removal from water. A review. Chemosphere. 93, 59-67, 2013.

19. CLARKE B.O., SMITH S.R. Review of 'emerging' organic contaminants in biosolids and assessment of 
international research priorities for the agricultural use of biosolids. Environment International 37, 226, 2011.

20. KÖCK-SCHULMEYER M., VILLAGRASA M., LÓPEZ DE ALDA M., CÉSPEDES-SÁNCHEZ R., VENTURA F., BARCELÓ D. Occurrence and behavior of pesticides in wastewater treatment plants and their environmental impact. Sci Total Environ. 458 (460), 466, 2013.

21. ROSINSKA A., KARWOWSKA B. Dynamics of changes in coplanar and indicator PCB in sewage sludge during mesophilic methane digestion. J. Hazard. Mater. 323 (A), 341, 2017.

22. PASSUELLO A., MARI M., NADAL M., SCHUHMACHER M., DOMINGO J.L. POP accumulation in the food chain: Integrated risk model for sewage sludge application in agricultural soils. Environ. Int. 36 (6), 577, 2010.

23. AGAMUTHU P., NARAYANAN K. Persistent organic pollutants in solid wastemanagement. Waste Manage. Res. 31 (10), 967, 2013.

24. HELALEH M.I.H., AL-RASHDAN A., IBTISAM A. Simultaneous analysis of organochlorinated pesticides (OCPs) and polychlorinated biphenyls (PCBs) from marine samples using automated pressurized liquid extraction (PLE) and Power Prep ${ }^{\mathrm{TM}}$ clean-up. Talanta. 94, 44, 2012.

25. FATOKI O.S., AWOFOLU R.O. Methods for selective determination of persistent organochlorine pesticide residues in water and sediments by capillary gas chromatography and electron-capture detection. J Chromatogr A. 983, 225, 2003.

26. NEKHAVHAMBE T.J., VAN REE T., FATOKI O.S. Determination and distribution of polycyclic aromatic hydrocarbons in rivers, surface runoff, and sediments in and around Thohoyandou, Limpopo Province, South Africa. Water SA. 40, 415, 2014.

27. RASHID A., NAWAZ S., BARKER H., AHMAD I., ASHRAF M. Development of a simple extraction and clean-up procedure for determination of organochlorine pesticides in soil using gas chromatography-tandem mass spectrometry. J Chromatogr A. 1217, 2933, 2010.

28. RATOLA N., CINCINELLI A., ALVES A., KATSOYIANNIS A. Occurrence of organic microcontaminants in the wastewater treatment process. A mini review. J Hazard Mater . 239 (240), 1, 2012.

29. WU C., ZHANG A., LIU W. Risks from sediments contaminated with organochlorine pesticides in Hangzhou, China. Chemosphere. 90, 2341, 2013.
30. SEBASTIAN W., MARIUSZ D. Analysis of Organic and Inorganic Contaminants in Dried Sewage Sludge and ByProducts of Dried Sewage Sludge Gasification. Energies. 7, 462, 2014.

31. ZENNEGG M., MUNOZ M., SCHMID P., GERCKE A.C. Temporal trends of persistent organic pollutants in digested sewage sludge (1993-2012). Environment International, 60, 202, 2013.

32. ZHAO C., XIE H., ZHANG J., XU J., LIANG S. Spatial distribution of organochlorine pesticides (0CPs) and effect factory. Chemosphere 90, 2381, 2013.

33. OLSHANSKY Y., POLUBESOVA T., VETTER W., CHEFETZ B. Sorption - desorption behavior of polybrominated diphenyl ethers in soils. Environnemental Pollution 159, 2375, 2011.

34. ILYAS M., SUDARYANTO A., SETIAWAN I.E., RIYADI A.S., ISOBE T., TANABE S. Characterization of polychlorinated biphenyls and brominated flame retardants in sludge, sediment and fish from municipal dumpsite at Surabaya, Indonesia. Chemosphere. 93(8), 1500, 2013.

35. HOAI P.M., NGOC N.T., MINH N.H., VIET P.H., BERG M., ALDER A., GIGER. Recent levels of organochlorine pesticides and polychlorinated biphenyls in sediments of the sewer system in Hanoi, Vietnam. Environmental Pollution 158, 913, 2010.

36. BARAKAT A.O., MOSTAFA A.R., WADE T.L., SWEET S.T., EL-SAYED N.B. Distribution and ecological risk of organochlorine pesticides and polychlorinated biphenyls in sediments from the Mediterranean coastal environment of Egypt. Chemosphere. 93 (3), 545, 2013.

37. WHO. WHO position on DDT use in disease vector control under the Stockholm Convention on Persistent Organic Pollutants. WHO Regional Office for Americas/ Pan American Sanitary Bureau (AMRO/PAHO) 525, $23^{\text {rd }}$ Street, N.W., Washington, DC 20037, USA 2004.

38. NOWAK K.M., MILTNER A., GEHRE M.,SCHÄFFER A., KÄSTNER M. Formation and fate of bound residues from mircrobial biomass during 2,4-D degradation in soil. Environmental Science and Technology 45, 999, 2011.

39. TEIJON G., CANDELA L., TAMOH K., MOLINADIAZ., FERNANDEZ-ALB A.R. Occurrence of emerging contaminants, priority substances (2008/105/CE) and heavy metals intreated wastewater and groundwater at Depurbaix facility (Barcelona, Spain). Science of the Total Environment 408, 3584, 2010. 